\title{
EFEK MODEL TANAH DENGAN BOUNDARY ELASTIC TERHADAP KAPASITAS LATERAL TIANG
}

\author{
Leon Yulio ${ }^{1}$, Hendy Wijaya ${ }^{2}$, dan Amelia Yuwono ${ }^{3}$ \\ ${ }^{1}$ Program Studi Sarjana Teknik Sipil, Universitas Tarumanagara, Jl. Letjen S. Parman No.1 Jakarta \\ leon.325160002@stu.untar.ac.id \\ ${ }^{2}$ Program Studi Sarjana Teknik Sipil, Universitas Tarumanagara, Jl. Letjen S. Parman No.1 Jakarta \\ rm.hendy@yahoo.com \\ ${ }^{3}$ Program Studi Sarjana Teknik Sipil, Universitas Tarumanagara, Jl. Letjen S. Parman No.1 Jakarta \\ yuwonoamelia@gmail.com
}

Masuk: 06-07-2020, revisi: 08-07-2020, diterima untuk diterbitkan: 05-08-2020

\begin{abstract}
Foundation is the most important part in building construction. Foundation has ability to hold axial force and lateral force. Foundation could be used for any kind of soil, for example like sandy soil and soft soil, etc. One kind of foundation that easy to use in practice is driven pile. Each foundation has its own strength to withstand load that occurs on surrounding soil. To be able to determine the capacity of the pile on the surrounding soil it is necessary to design a pile in accordance with the design requirements of SNI 8460:2017. The capacity of driven pile is really determined by lateral shear that works on surrounding soil. By giving boundary elastic around sandy soil, can be evaluated how much model of sand soil that should be modeled and determine its effect on the soil and pile. To be able to know that, it is necessary to analyze the numerical model using PLAXIS 3D program. The result obtained by giving a boundary elastic around sandy soil affect the behavior of the soil and piles analysed.
\end{abstract}

Keywords: foundation; driven pile; pile capacity; boundary elastic

\begin{abstract}
ABSTRAK
Fondasi adalah bagian terpenting dalam konstruksi sebuah bangunan. Fondasi memiliki kemampuan untuk menahan beban gaya aksial dan gaya lateral. Fondasi dapat digunakan dalam berbagai jenis tanah, seperti tanah pasir, tanah lunak, dll. Salah satu jenis fondasi yang mudah untuk digunakan dalam pelaksanaannya adalah tiang pancang. Setiap fondasi memiliki kekuatan masing-masing untuk menahan beban yang terjadi pada tanah disekitarnya. Untuk dapat mengetahui kapasitas tiang pada tanah disekitarnya perlu dilakukan perancangan tiang pancang yang sesuai dengan persyaratan desain SNI 8460:2017. Kapasitas fondasi tiang pancang sangat dipengaruhi dari tegangan lateral yang bekerja pada tanah disekitarnya. Dengan memberikan boundary elastic disekitar tanah pasir dapat dievaluasi seberapa besar model tanah pasir yang harus dimodelkan serta mengetahui pengaruhnya terhadap tanah dan tiang. Untuk dapat mengetahui hal tersebut maka perlu dianalisis dengan model numerik menggunakan program PLAXIS 3D. Hasil yang diperoleh dengan memberikan boundary elastic di sekitar tanah pasir mempengaruhi perilaku tanah dan tiang pancang yang dianalisis.
\end{abstract}

Kata kunci: fondasi; tiang pancang; kapasitas tiang; boundary elastic

\section{PENDAHULUAN}

Fondasi adalah bagian terpenting dalam konstruksi sebuah bangunan. Fondasi memiliki peran penting terhadap kekuatan bangunan, karena fondasi adalah struktur pertama yang berfungsi untuk menerima dan memikul beban. Beban yang ditahan oleh fondasi berupa beban aksial dan lateral. Beban aksial berupa beban dari konstruksi itu sendiri terhadap gravitasi, sedangkan beban lateral adalah beban yang disebabkan oleh angin atau gempa bumi.

Fondasi harus dapat digunakan dalam segala jenis tanah. Salah satu jenis fondasi yang populer digunakan adalah fondasi tiang pancang. Fondasi ini dipilih karena pelaksanaan yang mudah dan cepat. Fondasi tiang pancang digunakan pada tanah yang tidak memiliki daya dukung yang cukup untuk memikul berat konstruksi dan beban lainnya. 
Fondasi harus dapat memikul beban aksial dan lateral, oleh karena itu kapasitas fondasi harus dihitung dengan baik. Beban gempa merupakan beban yang harus diperhitungkan karena beban gempa memberikan gaya yang sangat signifikan terhadap fondasi. Fondasi sangat dipengaruhi oleh tanah disekitarnya. Komposisi tanah yang bermacam-macam akan mempengaruhi kekuatan dari fondasi tersebut.

Berdasarkan kondisi diatas, tugas akhir ini akan dilakukan analisis model tanah pasir yang diberikan boundary elastic. Boundary elastic adalah batasan berupa tanah elastis dengan material linear elastic. Untuk dapat melakukan analisis tersebut maka dapat digunakan program berbasis geoteknik. Hasil yang diperoleh dari analisis tersebut berupa efek model tanah terhadap kapasitas lateral tiang fondasi.

\section{METODE PENELITIAN}

Pada penelitian ini, data tanah diperlukan sebelum memulai analisis. Data tanah yang digunakan merupakan hasil korelasi dari studi literatur. Data tanah yang diperlukan berupa modulus elasticity, unit weight, poisson ratio, dan angle of internal friction yang menggunakan korelasi dari buku (Bowles, 1991) dan (Das, 2004). Pada tabel berikut menunjukkan parameter tanah yang digunakan dalam analisis ini.

Tabel 1. Parameter tanah

\begin{tabular}{cccc}
\hline Parameter & Symbol & \multicolumn{2}{c}{ Value } \\
\cline { 3 - 4 } & & Sand & Clay \\
\hline Modulus Elasticity $\left(\mathrm{kN} / \mathrm{m}^{2}\right)$ & $\mathrm{E}$ & 25000 & 100000 \\
Unit Weight wet $\left(\mathrm{kN} / \mathrm{m}^{3}\right)$ & $\gamma_{\text {wet }}$ & 16,69 & 13 \\
Unit Weight saturated $\left(\mathrm{kN} / \mathrm{m}^{3}\right)$ & $\gamma_{\text {sat }}$ & 17,95 & 14 \\
Poisson Ratio & $\mu$ & 0,3 & 0,2 \\
Angle of Internal friction $\left({ }^{\circ}\right)$ & $\phi$ & 30 & - \\
\hline
\end{tabular}

Setelah data tanah didapatkan, parameter tersebut dimasukkan kedalam program dan diatur pemodelannya. Perlu dibatasi seberapa dalam tanah pasir dan boundary elastic serta kekuatan dari tanah tersebut. Pada program geoteknik ini diperlukan pemilihan material yang digunakan untuk analisis (Manual PLAXIS 3D, 2013). Pada tabel 2 dan 3 menunjukkan pemodelan lapisan tanah pasir dam boundary elastic yang digunakan dalam analisis.

Tabel 2. Pemodelan lapisan tanah pasir

\begin{tabular}{ccccccc}
\hline Layer & Material & Depth $(\mathrm{m})$ & Sudut Geser $\left(^{\circ}\right)$ & Poisson Ratio & $\gamma_{\text {wet }}\left(\mathrm{kN} / \mathrm{m}^{3}\right)$ & $\gamma_{\text {sat }}\left(\mathrm{kN} / \mathrm{m}^{3}\right)$ \\
\hline 1 & Mohr-Coulomb & $0 \mathrm{~s} / \mathrm{d}-20$ & 30 & 0,3 & 16,69 & 17,95 \\
\hline
\end{tabular}

Tabel 3. Pemodelan lapisan boundary elastic

\begin{tabular}{ccccccc}
\hline Layer & Material & Depth $(\mathrm{m})$ & Modulus Elasticity $\left(\mathrm{kN} / \mathrm{m}^{2}\right)$ & Poisson Ratio & $\gamma_{\text {wet }}\left(\mathrm{kN} / \mathrm{m}^{3}\right)$ & $\gamma_{\text {sat }}\left(\mathrm{kN} / \mathrm{m}^{3}\right)$ \\
\hline 1 & Linear-Elastic & $0 \mathrm{~s} / \mathrm{d}-20$ & 100000 & 0,2 & 13 & 14
\end{tabular}

Dalam analisis penentuan dimensi tanah yang akan di analisis. Pembatasan dilakukan agar cakupan analisis tidak terlalu luas. Pada gambar berikut menunjukkan pemodelan dalam program PLAXIS 3D dengan warna coklat menunjukkan boundary elastic dan biru menunjukkan tanah pasir.
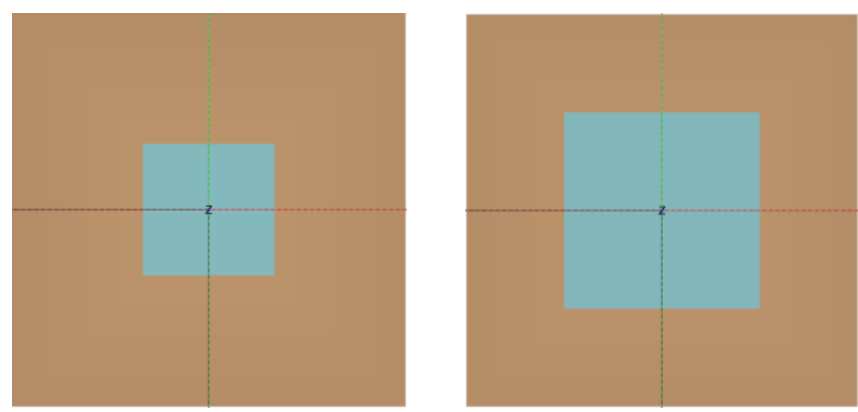

Gambar 1. Model boundary elastic dengan tanah 20x20m dan model boundary elastic dengan tanah 30x30m 

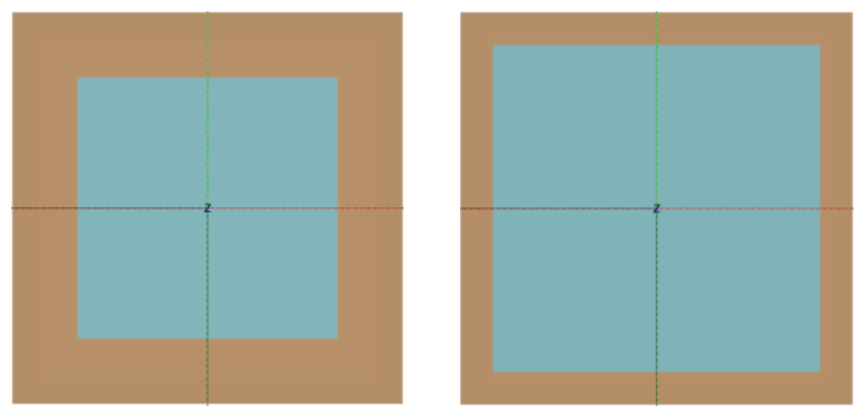

Gambar 2. Model boundary elastic dengan tanah 40x40m dan model boundary elastic dengan tanah 50x50m

Dalam analisis ini digunakan tiang kelompok berjumlah 4 dan 9 dengan jarak antar tiang sebesar 2D, 3D, 5D dan 7D yang menyesuaikan jarak ideal berdasarkan buku (Reese \& Impe, 2001). Pada gambar dibawah ini menampilkan konfigurasi 4 dan 9 tiang kelompok yang dianalisis dengan menggunakan program berbasis geoteknik yang mengacu pada jurnal (Putraloka, 2020). Gambar (a) adalah Top View dan Gambar (b) adalah Perspective View

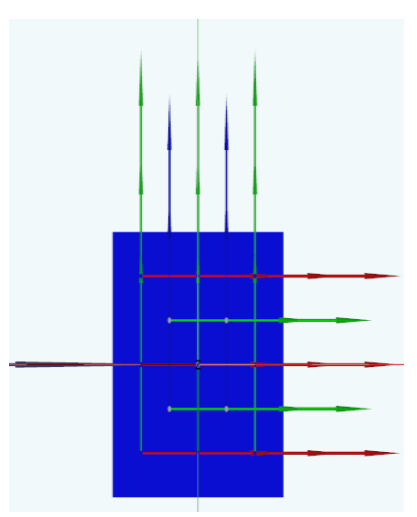

(a)

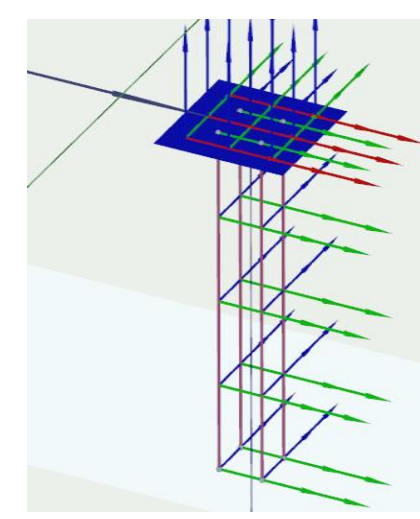

(b)

Gambar 3. Konfigurasi 4 tiang dengan jarak antar tiang 2D

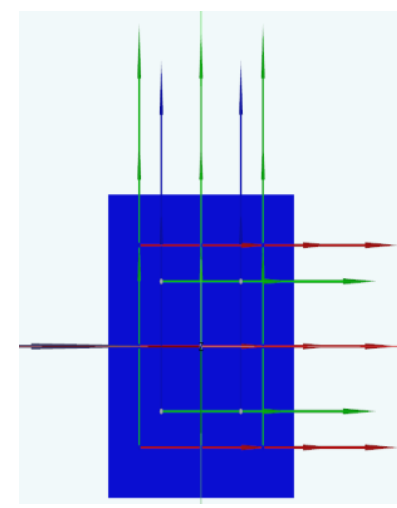

(a)

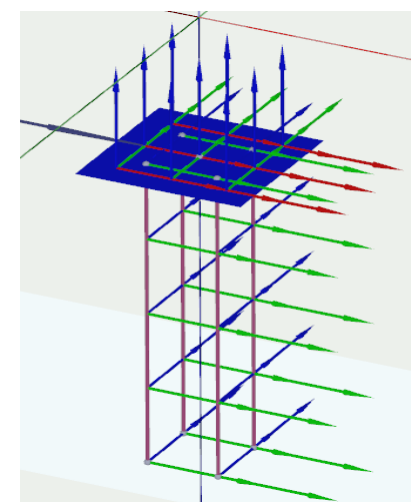

(b)

Gambar 4. Konfigurasi 4 tiang dengan jarak antar tiang 3D 


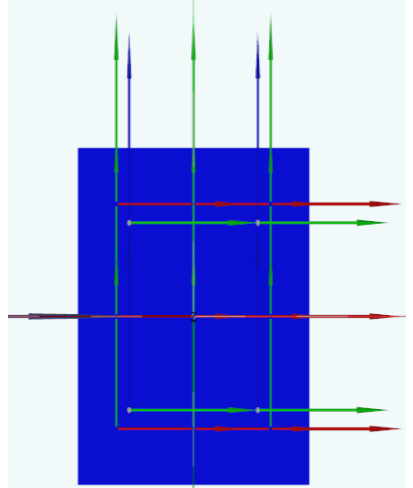

(a)

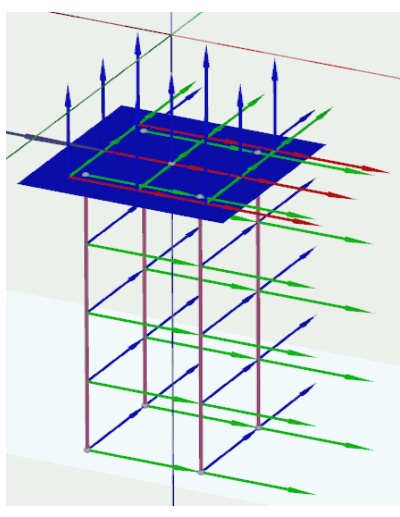

(b)

Gambar 5. Konfigurasi 4 tiang dengan jarak antar tiang 5D

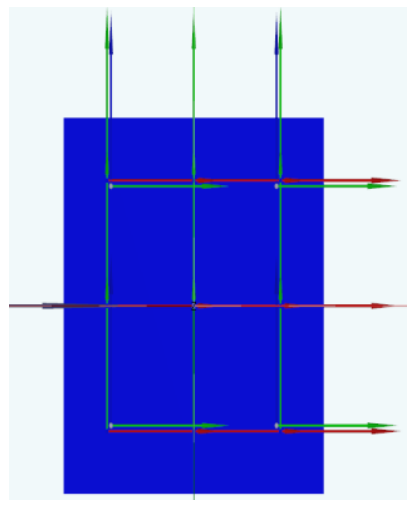

(a)

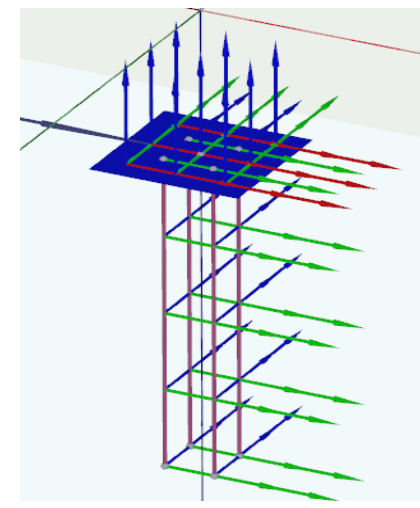

(b)

Gambar 6. Konfigurasi 4 tiang dengan jarak antar tiang 7D

Beban dimasukkan kedalam program dengan arah lateral yang dinaikkan secara bertahap hingga tiang mencapai beban maksimum yang dapat dipikul. Pada gambar dibawah ini menampilkan pembebanan yang digunakan dalam program.

Initial phase [InitialPhase]
Excavation [Phase_1]
Struktur [Phase_2]
Reset displacement to zero [Phase_3]
Load 10KN [Phase_4]
Load 50KN [Phase_5]
Load 100KN [Phase_6]
Load 500KN [Phase_7]
Load 1000KN [Phase_8]
Load 2000KN [Phase_9]
Load 3000KN [Phase_10]
Load 4000KN [Phase_11]
Load 5000KN [Phase_12]
Load 6000KN [Phase_13]
Load 7000KN [Phase_14]
Load 8000KN [Phase_15]
Load 9000KN [Phase_16]
Load 10000KN [Phase_17]

Gambar 7. Input beban yang digunakan 


\section{HASIL DAN PEMBAHASAN}

\section{Hasil analisis 4 tiang persegi dengan model tanah 20x20m dengan $\mathrm{s}=2 \mathrm{D}$}

Penomoran pada tiang dilakukan agar dapat memudahkan dalam membedakan posisi tiang dalam pile cap dan menunjukkan bagaimana bentuk konfigurasi tiang dalam pile cap. Pada gambar berikut menunjukkan penomoran tiang dalam pile cap.

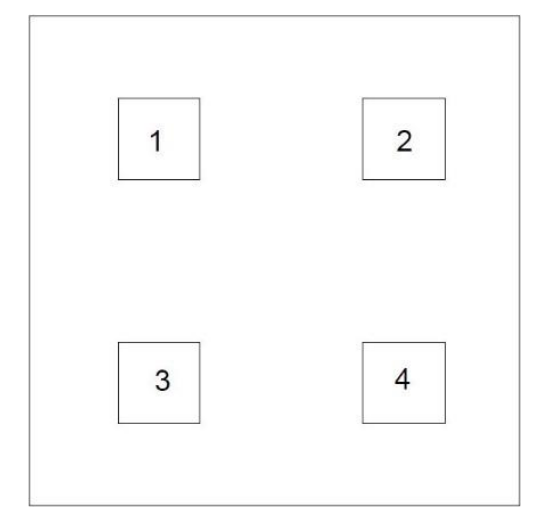

Gambar 8. Tiang kelompok dengan 4 tiang

\section{Displacement}

Berikut merupakan hasil displacement dari 4 tiang tersebut. Displacement yang dihasilkan dari analisis ini memiliki nilai yang cenderung mirip pada beban yang sudah mencapai $10000 \mathrm{kN}$. Pada tabel dibawah ini menunjukkan hubungan dari displacement dari keempat tiang dengan load yang bekerja.

Tabel 4. Hasil output tiang model tanah 20x20m dengan $\mathrm{s}=2 \mathrm{D}$

\begin{tabular}{ccccc}
\hline $\begin{array}{c}\text { Load } \\
(\mathrm{kN})\end{array}$ & $\begin{array}{c}\text { Displacement }(\mathrm{m}) \\
\text { Tiang 1 }\end{array}$ & $\begin{array}{c}\text { Displacement }(\mathrm{m}) \\
\text { Tiang 2 }\end{array}$ & $\begin{array}{c}\text { Displacement }(\mathrm{m}) \\
\text { Tiang 3 }\end{array}$ & $\begin{array}{c}\text { Displacement }(\mathrm{m}) \\
\text { Tiang } 4\end{array}$ \\
\hline 0 & 0 & 0 & 0 & 0 \\
10 & 0,00005941 & 0,00006115 & 0,00005952 & 0,00005855 \\
50 & 0,0002969 & 0,0003080 & 0,0002971 & 0,0002949 \\
100 & 0,0005925 & 0,0006236 & 0,0005945 & 0,0005977 \\
500 & 0,002957 & 0,003398 & 0,003187 & 0,003245 \\
1000 & 0,006667 & 0,007788 & 0,007393 & 0,007275 \\
2000 & 0,01716 & 0,01953 & 0,01906 & 0,01805 \\
3000 & 0,03109 & 0,03463 & 0,03415 & 0,03229 \\
4000 & 0,04803 & 0,05254 & 0,05213 & 0,04953 \\
5000 & 0,06856 & 0,07367 & 0,07346 & 0,07008 \\
6000 & 0,09286 & 0,09827 & 0,09835 & 0,09440 \\
7000 & 0,1214 & 0,1269 & 0,1275 & 0,1230 \\
8000 & 0,1554 & 0,1607 & 0,1619 & 0,1570 \\
9000 & 0,1954 & 0,1999 & 0,2019 & 0,1967 \\
10000 & 0,2419 & 0,2455 & 0,2483 & 0,2426 \\
\hline
\end{tabular}

Setelah hasil displacement didapatkan, dilakukan plotting displacement terhadap beban yang digunakan dalam program. Displacement akan memiliki nilai yang semakin besar jika beban yang diterima besar juga. Displacement yang dihasilkan cenderung sama walaupun memiliki posisi yang berbeda dalam pile cap. Pada gambar dibawah ini menunjukkan dengan jelas hubungan antara displacemet dan load dari keempat tiang. 
Efek Model Tanah dengan Boundary Elastic terhadap Leon Yulio, et al. Kapasitas Lateral Tiang

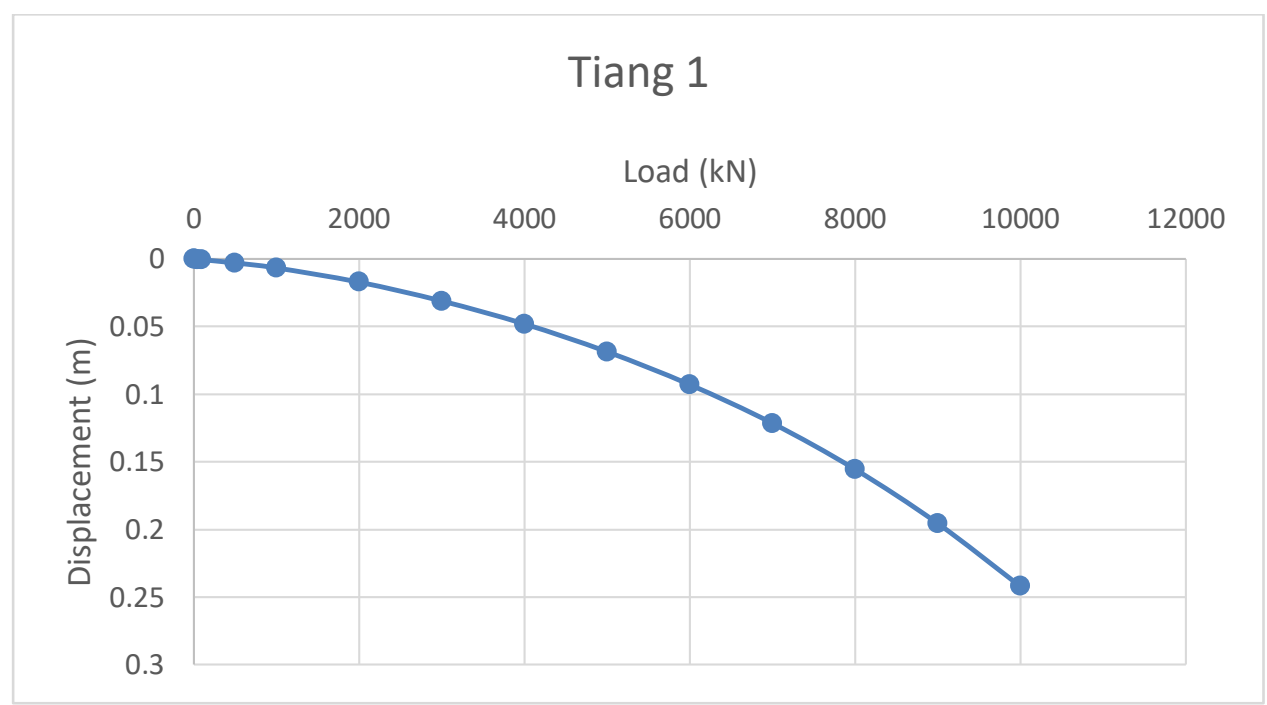

Gambar 9. Kurva hubungan load dan displacement tiang 1 model tanah 20x20m dengan s=2D

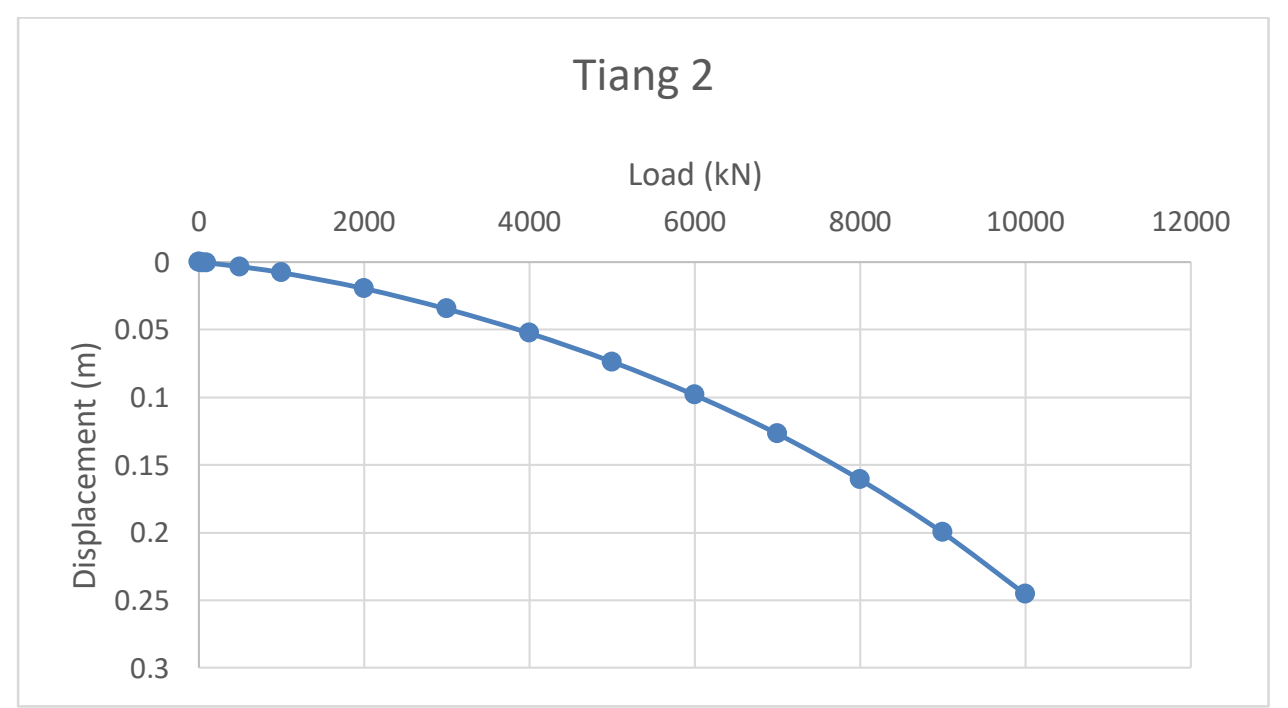

Gambar 10. Kurva hubungan load dan displacement tiang 2 model tanah 20x20m dengan s=2D

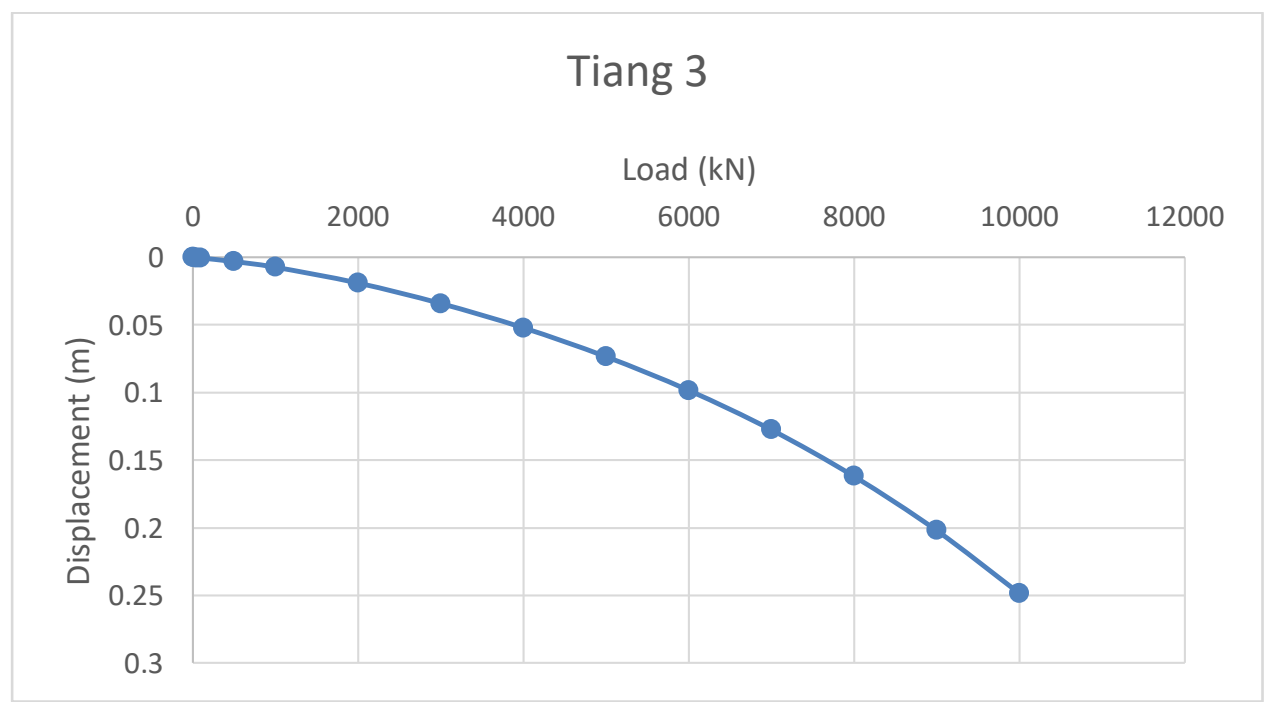

Gambar 11. Kurva hubungan load dan displacement Tiang 3 model tanah 20x20m dengan s=2D 


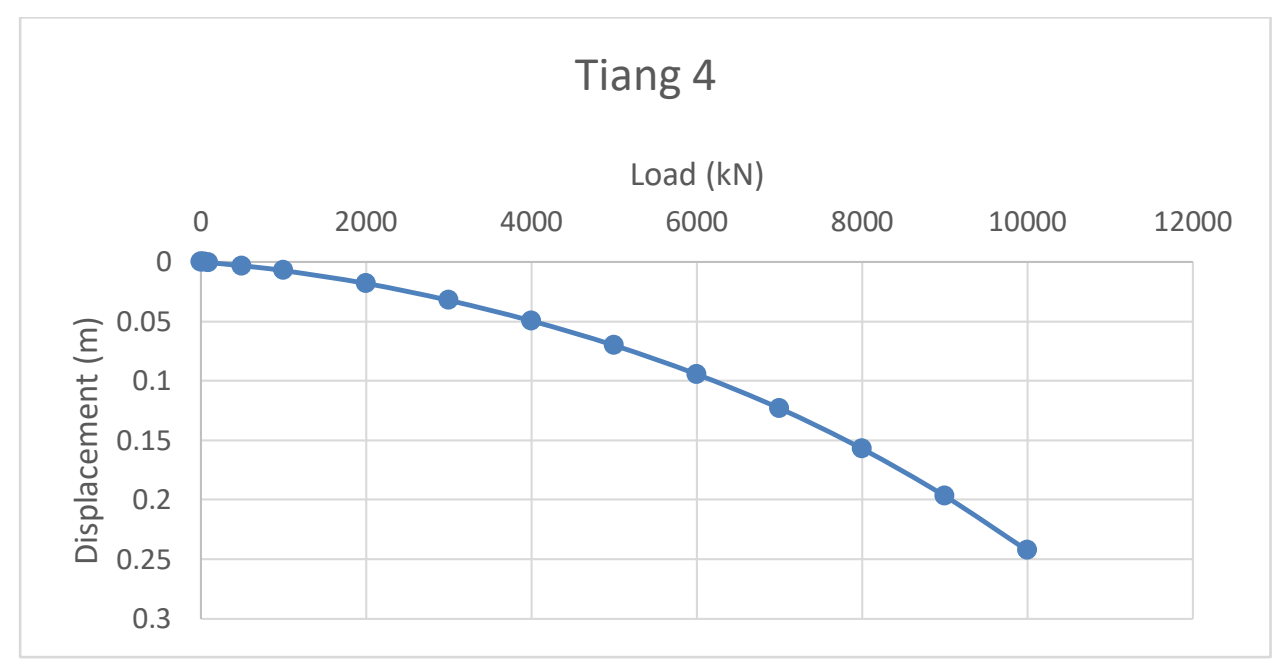

Gambar 12. Kurva hubungan load dan displacement tiang 4 model tanah 20x20m dengan s=2D

\section{Bending moment}

Kapasitas lateral dari sebuah tiang dapat diketahui dengan melihat besaran bending moment yang dihasilkan dari analisis yang dilakukan. Bending moment yang dihasilkan dalam analisis ini memiliki perbedaan yang tergantung dari posisi tiang. Tiang dengan posisi leading $(2,4)$ memiliki bending moment yang lebih kecil dibandingkan dengan tiang dalam posisi trailing $(1,3)$. Hasil yang didapatkan sesuai dengan jurnal yang dipublikasi oleh (Chen, Poulos, \& Hull, 1997). Pada tabel dibawah ini menunjukkan nilai dari bending moment keempat tiang dan hubungannya dengan beban yang diterima.

Tabel 5. Bending moment model tanah 20x20m dengan s=2D

\begin{tabular}{ccccc}
\hline $\begin{array}{c}\text { Load } \\
(\mathrm{kN})\end{array}$ & $\begin{array}{c}\text { Bending } \\
\text { Moment } \\
(\mathrm{kNm}) \text { Tiang 1 }\end{array}$ & $\begin{array}{c}\text { Bending } \\
\text { Moment } \\
(\mathrm{kNm}) \text { Tiang 2 }\end{array}$ & $\begin{array}{c}\text { Bending } \\
\text { Moment } \\
(\mathrm{kNm}) \text { Tiang 3 }\end{array}$ & $\begin{array}{c}\text { Bending } \\
\text { Moment } \\
(\mathrm{kNm}) \text { Tiang 4 }\end{array}$ \\
\hline 0 & 0 & 0 & 0 & 0 \\
10 & 0,3 & 0,54 & 0,42 & 0,47 \\
50 & 1,76 & 2,12 & 2,10 & 2,13 \\
100 & 3,70 & 4,13 & 4,41 & 4,30 \\
500 & 20,45 & 21,61 & 28,26 & 22,47 \\
1000 & 50,04 & 50,65 & 68,93 & 47,86 \\
2000 & 129,46 & 124,83 & 175,94 & 115,17 \\
3000 & 223,95 & 209,58 & 302,62 & 199,14 \\
4000 & 325,91 & 301,55 & 440,72 & 296,35 \\
5000 & 429,56 & 395,46 & & 402,86 \\
6000 & & 489,41 & & \\
\hline
\end{tabular}

Hasil bending moment di plot dengan kedalaman dan beban yang diterima. Hasil plot menunjukkan bahwa bending moment memiliki nilai maksimum ketika berada di posisi tengah tiang $(-10 \mathrm{~m}$ dari permukaan tanah). Membandingkan hasil plotting seperti pada jurnal (Haskell, Madabhushi, \& Cubrinovski, 2011) untuk melihat pengaruh jarak antar tiang terhadap tiang. Pada gambar berikut menunjukkan hubungan dari bending moment dari keempat tiang yang terjadi dengan kedalaman tiang serta beban yang diterima. 
Efek Model Tanah dengan Boundary Elastic terhadap Leon Yulio, et al. Kapasitas Lateral Tiang

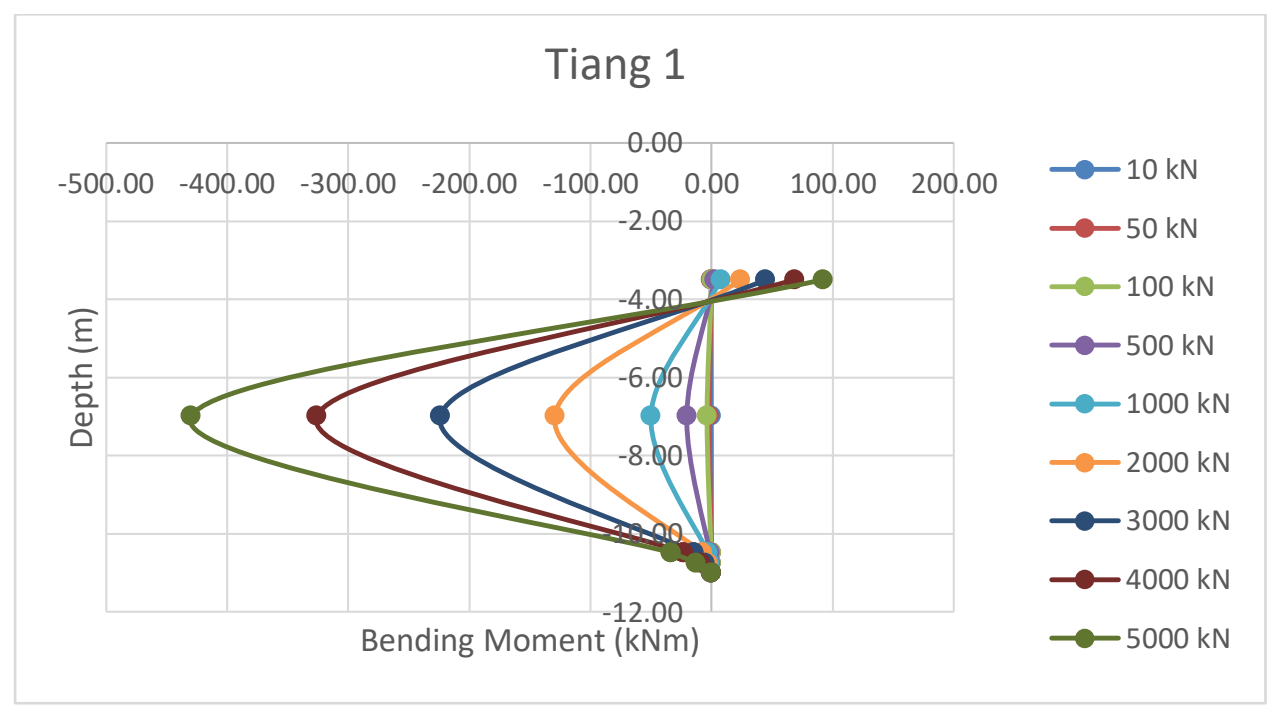

Gambar 13. Plot bending moment dengan kedalaman tiang 1 model tanah 20x20m dengan s=2D

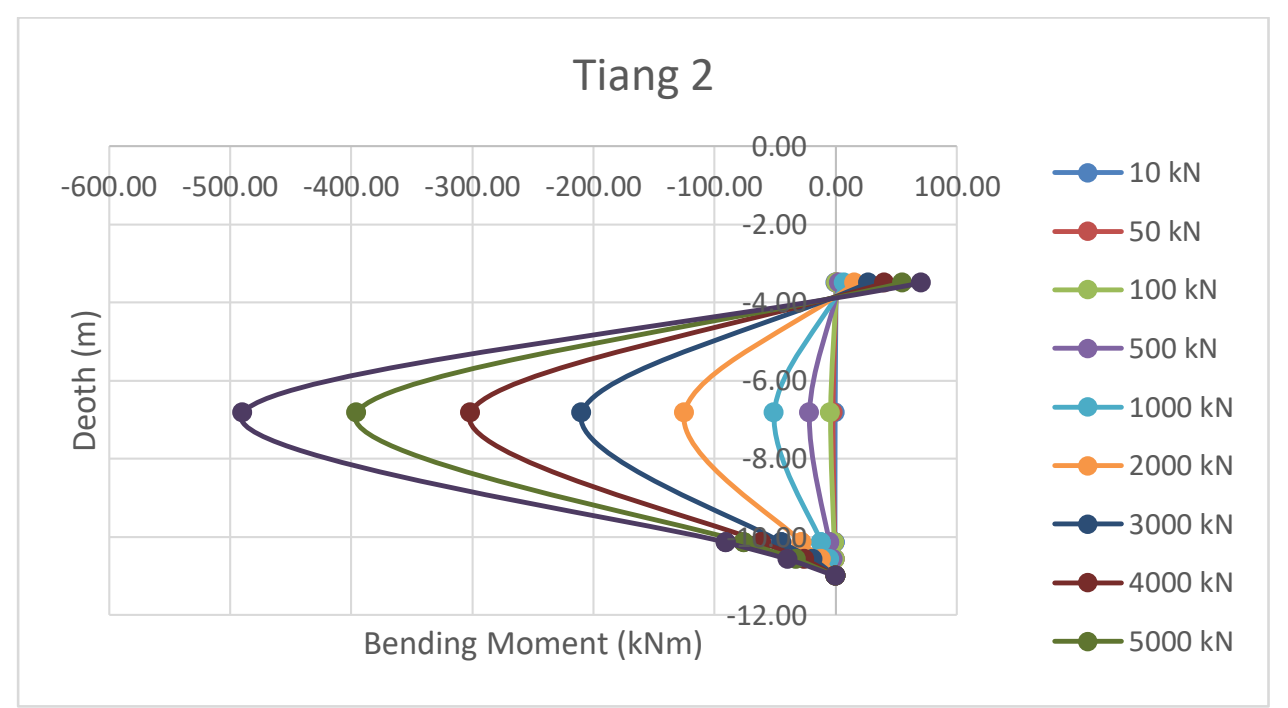

Gambar 14. Plot bending moment dengan kedalaman tiang 2 model tanah 20x20m dengan s=2D

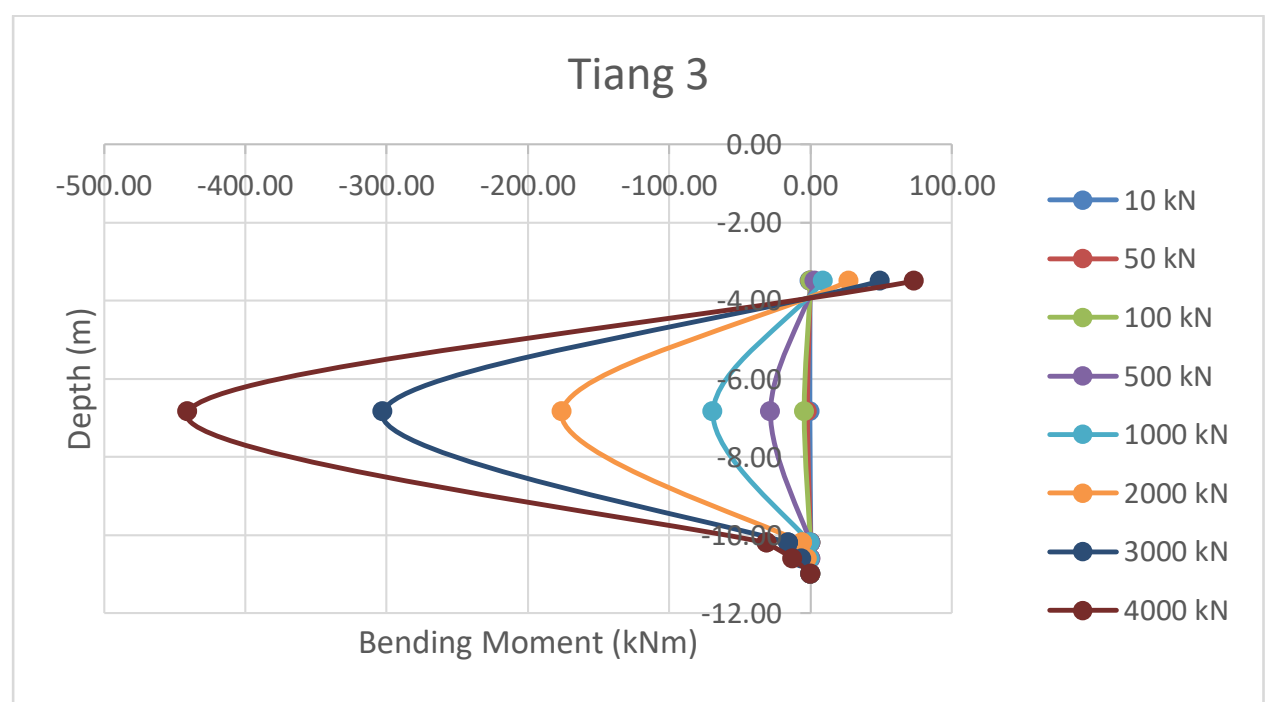

Gambar 15. Plot bending moment dengan kedalaman tiang 3 model tanah 20x20m dengan s=2D 


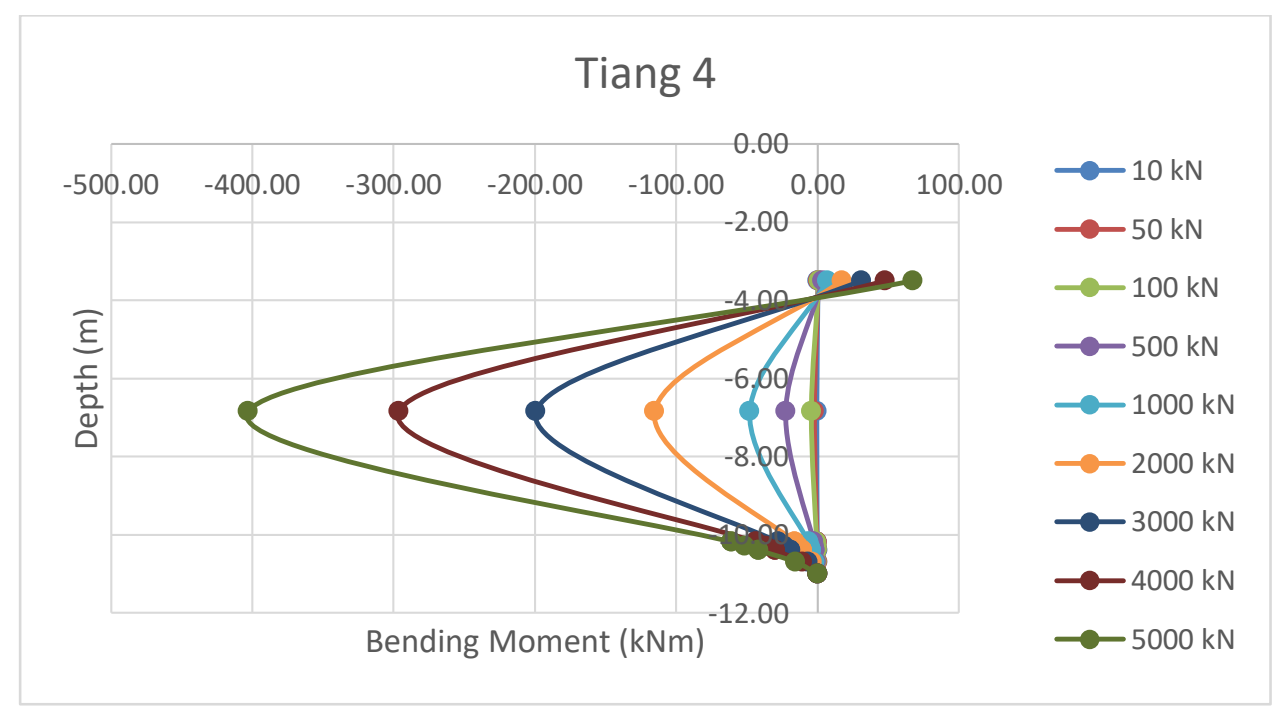

Gambar 16. Plot bending moment dengan kedalaman tiang 4 model tanah 20x20m dengan s=2D

\section{Shear capacity}

Setelah bending moment, shear capacity juga perlu dibandingkan untuk memberikan gambaran jelas terhadap kapasitas lateral dari pemodelan yang dilakukan. Shear capacity yang dihasilkan dari analisis juga memiliki nilai yang berbeda dengan tiang pada posisi leading $(2,4)$ memiliki nilai yang lebih kecil dibandingkan dengan tiang pada posisi trailing $(1,3)$. Pada tabel berikut menunjukkan hubungan dari shear capacity yang terjadi dari keempat tiang dengan beban yang diterima.

Tabel 6. Shear capacity model tanah $20 \times 20 \mathrm{~m}$ dengan $\mathrm{s}=2 \mathrm{D}$

\begin{tabular}{ccccc}
\hline $\begin{array}{c}\text { Load } \\
(\mathrm{kN})\end{array}$ & $\begin{array}{c}\text { Shear Capacity } \\
(\mathrm{kN}) \text { Tiang } 1\end{array}$ & $\begin{array}{c}\text { Shear Capacity } \\
(\mathrm{kN}) \text { Tiang 2 }\end{array}$ & $\begin{array}{c}\text { Shear Capacity } \\
(\mathrm{kN}) \text { Tiang } 3\end{array}$ & $\begin{array}{c}\text { Shear Capacity } \\
(\mathrm{kN}) \text { Tiang 4 }\end{array}$ \\
\hline 0 & 0 & 0 & 0 & 0 \\
10 & 0,38 & 1,14 & 0,66 & 0,89 \\
50 & 0,95 & 1,48 & 1,30 & 1,53 \\
100 & 2,17 & 2,74 & 2,76 & 2,94 \\
500 & 12,66 & 13,76 & 18,42 & 14,69 \\
1000 & 31,55 & 31,89 & 45,30 & 30,97 \\
2000 & 83,24 & 78,23 & 116,35 & 74,35 \\
3000 & 145,53 & 131,71 & 200,51 & 128,87 \\
4000 & 212,89 & 190,70 & 291,57 & 192,40 \\
5000 & 280,88 & 251,73 & & 262,36 \\
6000 & & 313,27 & & \\
\hline
\end{tabular}

Nilai dari shear capacity yang didapatkan di plotting dengan kedalaman dan beban yang diterima. Berbeda dengan bending moment, nilai maksimum yang diterima dapat terletak dikepala tiang maupun di ujung tiang tersebut. Hal tersebut dapat dilihat dari plotting yang sudah dilakukan. Pada gambar berikut menunjukkan hubungan dari nilai shear capacity yang terjadi dari keempat tiang dengan kedalaman tiang serta beban yang diterima. 


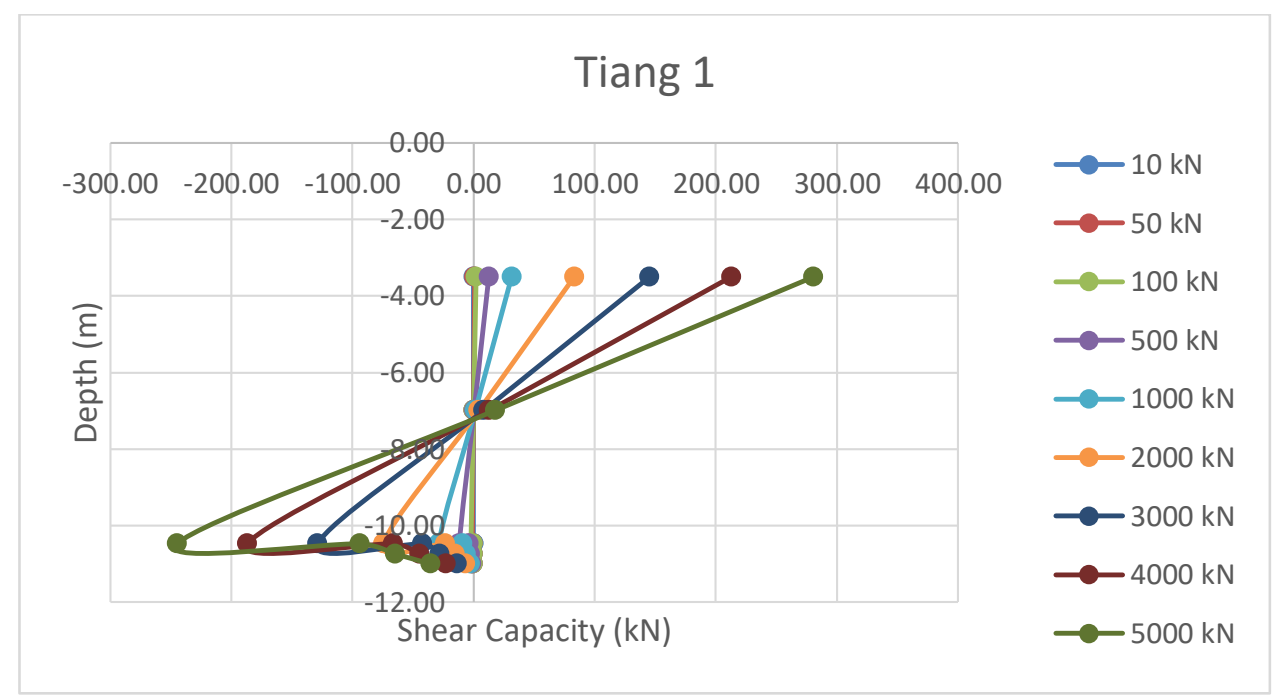

Gambar 17. Plot shear capacity dengan kedalaman tiang 1 model tanah 20x20m dengan s=2D

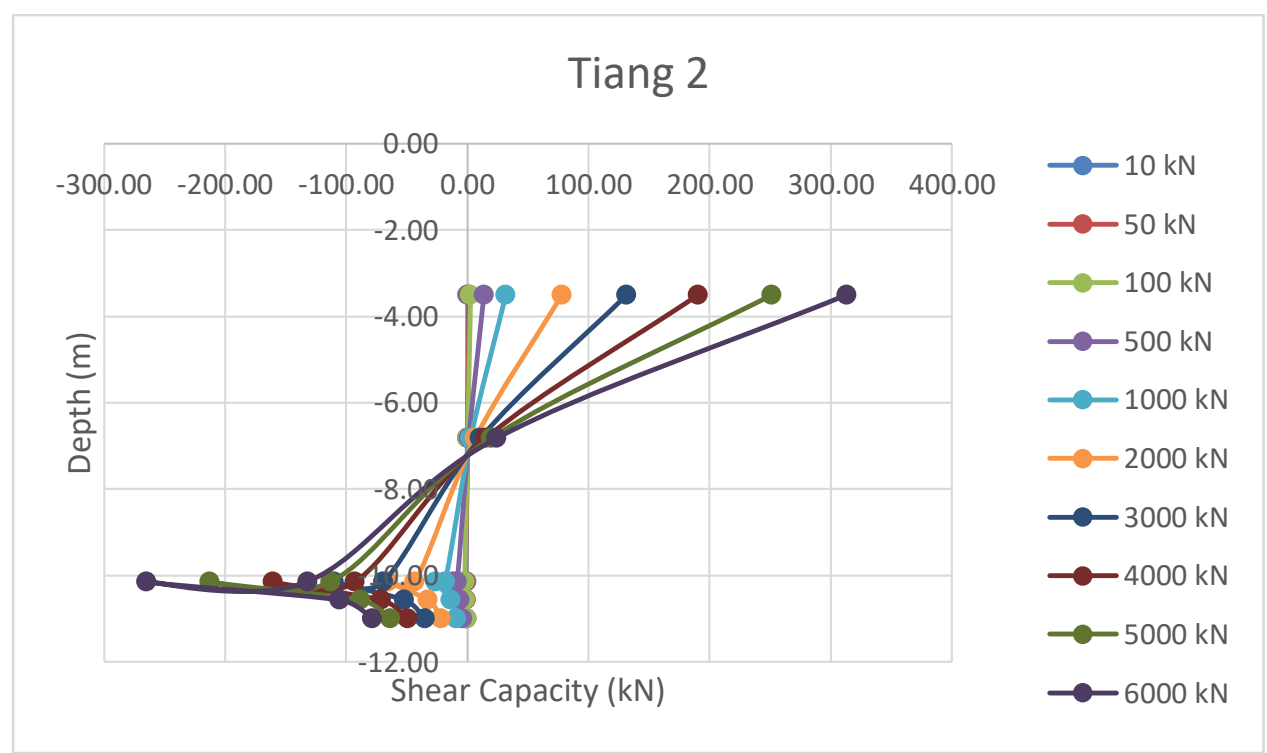

Gambar 18. Plot shear capacity dengan kedalaman tiang 2 model tanah 20x20m dengan s=2D

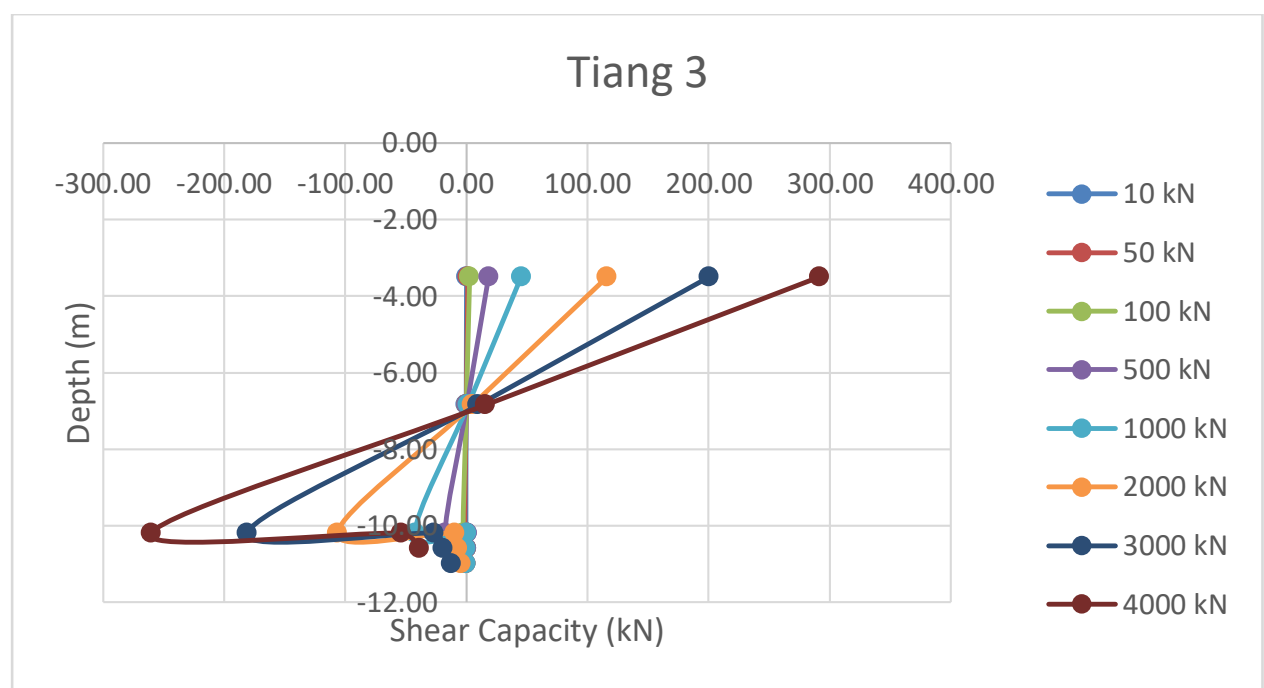

Gambar 19. Plot shear capacity dengan kedalaman tiang 3 model tanah 20x20m dengan s=2D 


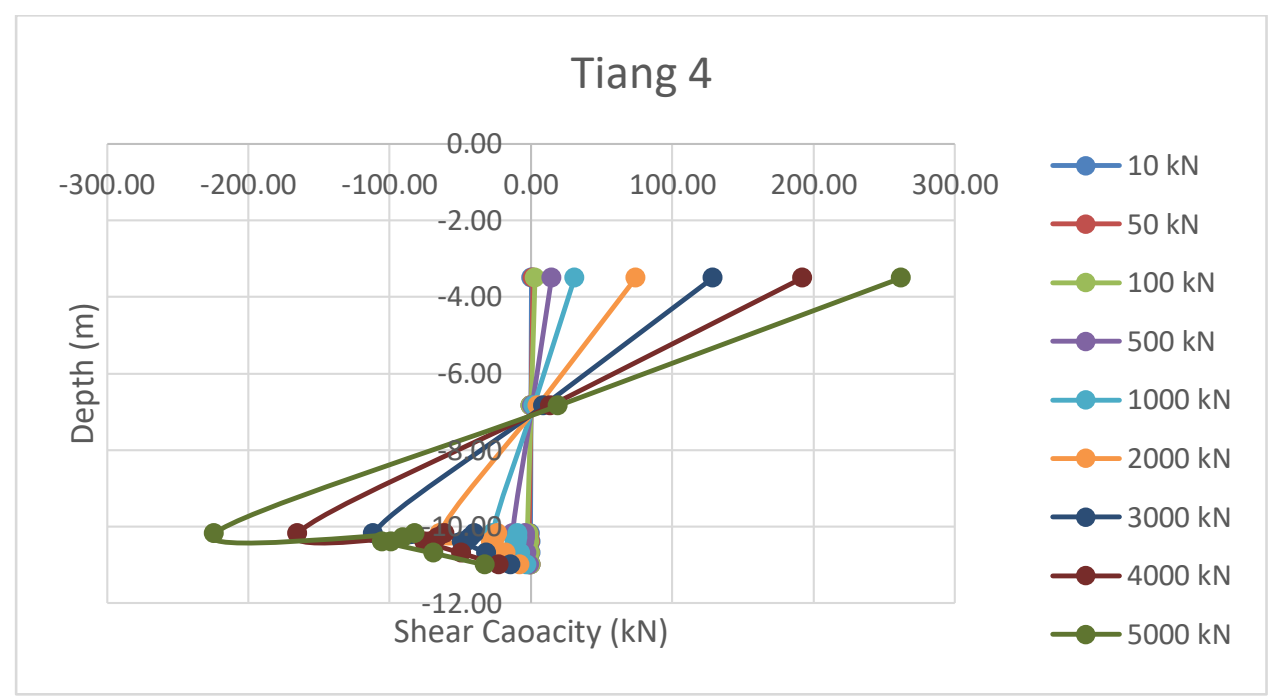

Gambar 20. Plot shear capacity dengan kedalaman tiang 4 model tanah 20x20m dengan s=2D

\section{Potongan deformasi dengan fixities 4 tiang persegi dengan model tanah 20x20m dengan s=2D}

Pada analisis ini, dilakukan juga potongan untuk memberikan gambaran tentang daerah yang terpengaruh dari pemodelan ini. Berdasarkan hasil yang didapat daerah yang terpengaruh cenderung lebih besar ke arah kanan, Pada setiap beban yang diterima akan menunjukkan perubahan dari daerah pengaruh tersebut. Pada gambar dibawah ini menampilkan potongan dari tanah yang menunjukkan daerah pengaruh beban terhadap fixities dari model tanah tersebut.

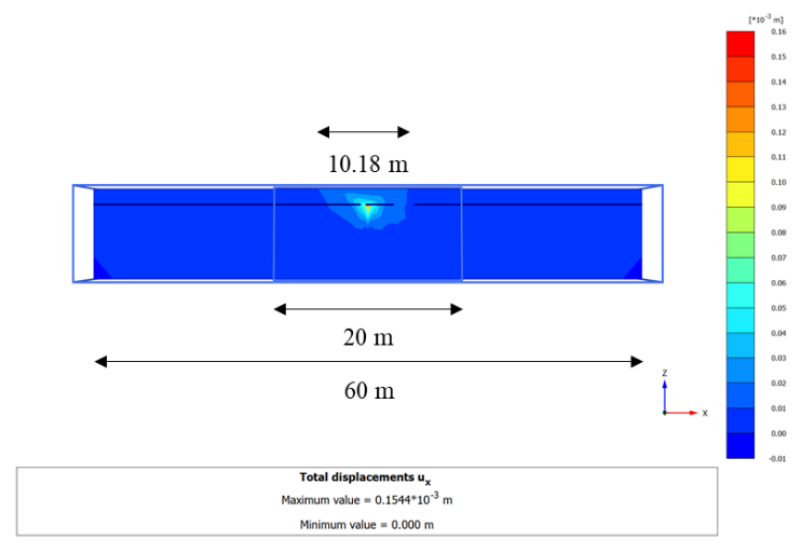

Gambar 21. Daerah pengaruh beban $10 \mathrm{kN}$ terhadap fixities model tanah 20x20m dengan s=2D

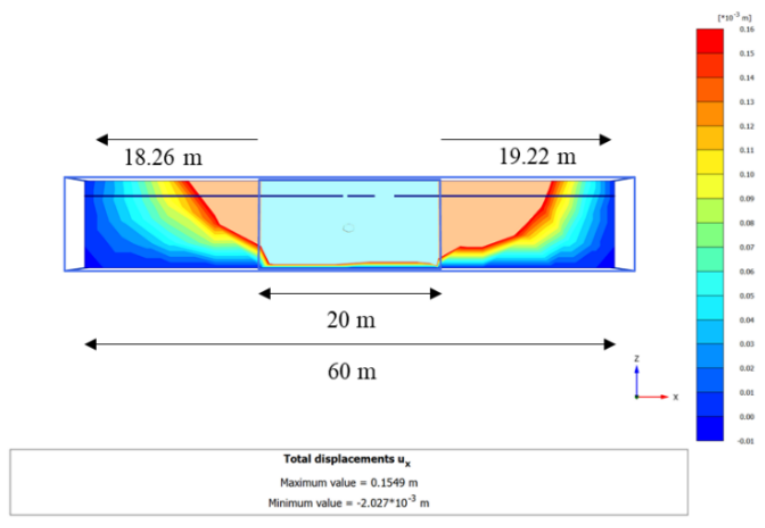

Gambar 22. Daerah pengaruh beban $5000 \mathrm{kN}$ terhadap fixities model tanah 20x20m dengan s=2D 


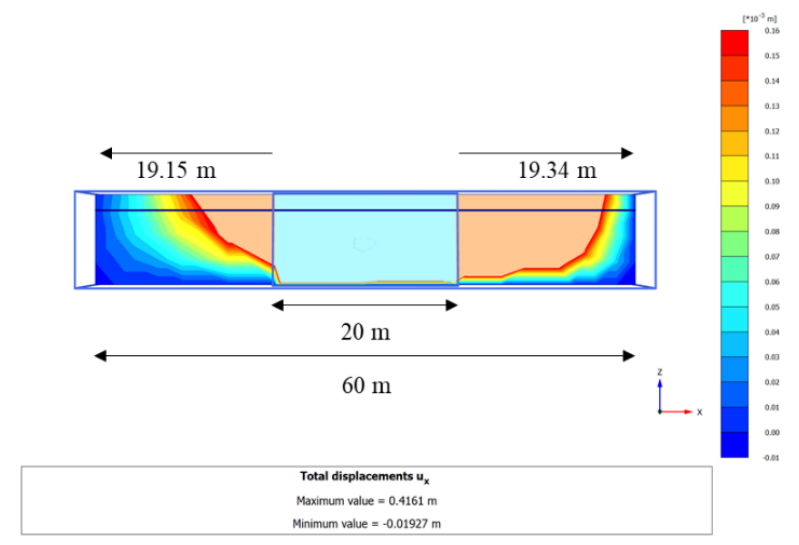

Gambar 23. Daerah pengaruh beban $10000 \mathrm{kN}$ terhadap fixities model tanah 20x20m dengan s=2D

\section{KESIMPULAN DAN SARAN}

\section{Kesimpulan}

1. Efek dari modelisasi dari boundary elastic terhadap tiang dan tanah adalah mengurangi displacement dan memperkuat daya dukung tiang terhadap gaya lateral.

2. Berdasarkan hasil analisis, jarak antar tiang dan tanah terhadap boundary elastic yang menurut penulis efektif adalah 5D dan tanah berjarak $20 \mathrm{~m}$ terhadap boundary elastic karena bending moment dan shear capacity yang didapatkan mengalami penguatan yang cukup signifikan.

3. Model yang menghasilkan displacement terbesar adalah model 4 tiang persegi yang memiliki dimensi tanah pasir 40x40m dengan s=2D, model yang menghasilkan bending moment terbesar adalah model 4 tiang persegi yang memiliki dimensi tanah pasir 20x20m dengan s=2D, model yang menghasilkan shear capacity terbesar adalah model 4 tiang persegi yang memiliki dimensi tanah pasir 30x30m dengan s=3D, model yang menghasilkan displacement terkecil adalah model 9 tiang spun yang memiliki dimensi tanah pasir 50x50m dengan s=7D, model yang menghasilkan bending moment terkecil adalah model 9 tiang spun yang memiliki dimensi tanah pasir 50x50m dengan s=7D, model yang menghasilkan shear capacity terkecil adalah model 9 tiang spun yang memiliki dimensi tanah pasir 50x50m dengan s=7D.

4. Semakin kecil dimensi tanah maka daerah pengaruh terhadap fixities akan semakin dalam.

5. Jarak antar tiang tidak mempengaruhi daerah pengaruh terhadap fixites.

\section{Saran}

1. Dapat dilakukan penelitian dengan ukuran dan jenis tiang yang berbeda.

2. Dilakukan studi lanjutan dengan gaya dinamik maupun gaya lateral yang berbeda.

3. Menggunakan konfigurasi tiang yang berbeda.

4. Membuat parameter yang berbeda dengan yang sudah dimodelkan sebelumnya untuk boundary elastic dan tanah.

\section{DAFTAR PUSTAKA}

Bowles, Joseph E. Analisis Dan Desain Pondasi Jilid 1. Jakarta: Erlangga, 1991.

Bowles, Joseph E. Analisis Dan Desain Pondasi Jilid 2. Jakarta: Erlangga, 1991.

Bowles, Joseph E. Foundation Analysis and Design Fifth Edition. New York: The McGraw-Hill, 1997.

Chen, L. T., H. G. Poulos and T. S. Hull. "Soil and Foundation." Model Test on Pile Groups Subjected to Lateral Soil Movement (1997): Vol 37, no1,1-12.

Das, Braja M. Principles of Foundation Engineering Seventh Edition. Pacific Grove: Thomson/Broke/Cole, 2004.

Haskell, Jeniffer, Gopal Madabhushi and Misko Cubrinovski. Effect on Pile Spacing on The Behaviour Of a Pile Group In Laterally Spreading Soil (2011): 10-13.

"Manual PLAXIS 3D." (2013).

Putraloka, Bagas. "Analisis Sendi Plastis Pada Pushover Kelompok Tiang Pancang." (2020).

Reese, Lymon C. and William F. Van Impe. Single Piles and Pile Groups Under Lateral Loading. London: Taylor \& Francis/Balkema, 2001. 